\title{
Tropical Fruit Pulps: Processing, Product Standardization and Main Control Parameters for Quality Assurance
}

\author{
Carlos Eduardo de Farias Silva ${ }^{1,2 *}$, Ana Karla de Souza Abud ${ }^{3}$ \\ ${ }^{1}$ Universita degli Studi di Padova - Department of Industrial Engineering Via Marzolo, Italy; ${ }^{2}$ Universidade \\ Federal de Alagoas - Centro de Tecnologia, Maceio, Brasil; ${ }^{3}$ Universidade Federal de Sergipe - DTA São \\ Critovão, Sergipe, Brasil.
}

\begin{abstract}
Fruit pulp is the most basic food product obtained from fresh fruit processing. Fruit pulps can be cold stored for long periods of time, but they also can be used to fabricate juices, ice creams, sweets, jellies and yogurts. The exploitation of tropical fruits has leveraged the entire Brazilian fruit pulp sector due mainly to the high acceptance of their organoleptic properties and remarkable nutritional facts. However, several works published in the last decades have pointed out unfavorable conditions regarding the consumption of tropical fruit pulps. This negative scenario has been associated with unsatisfactory physico-chemical and microbiological parameters of fruits pulps as outcomes of little knowledge and improper management within the fruit pulp industry. There are protocols for delineating specific identity and quality standards (IQSs) and standardized good manufacturing practices (GMP) for fruit pulps, which also embrace standard operating procedures (SOPS) and hazard analysis and critical control points (HACCP), although this latter is not considered mandatory by the Brazilian legislation. Unfortunately, the lack of skilled labor, along with failures in complying established protocols have impaired quality of fruit pulps. It has been necessary to collect all information available with the aim to identify the most important hazards within fruit pulp processing lines. Standardizing methods and practices within the Brazilian fruit pulp industry would assurance high quality status to tropical fruit pulps and the commercial growth of this vegetal product towards international markets.
\end{abstract}

Key words: processing, standards of identity and quality, vegetable product, food safety.

\footnotetext{
*Author for correspondence: eduardo.farias.ufal@gmail.com
} 


\section{INTRODUCTION}

Quality is increasingly referred to as an important element within the food industry. The growing demand for high quality food products has disseminated the use of quality management tools to meet expectations of consumers and market throughout the world, and also to manufacture safe products, thereby reducing costs and production losses ${ }^{1}$.

Consumer expectations are much more demanding than in the past. Nowadays, there are major concerns related to food safety (pathogenic microorganisms and harmful substances) and food quality that involve various aspects, from the entire production chain up to fair labor payments and environmental impacts to soil and water. The rapidly increasing demand for fresh fruits has reflected changes in consumer preferences for healthier foods, which should also be produced through environmentally friendly processes ${ }^{2}$.

Brazil is an essentially agricultural country with a huge potential for cultivating traditional and exotic fruits. Fruit pulp is the most basic product obtained from fresh fruit processing, although its production and conservation have not been correctly accomplished in Brazil. In the last decades, numerous studies have pointed out the technological inadequacy of Brazilian fruit pulps for human consumption, which reflect lack of qualified labor, standardized processing methods and good manufacturing practices (GMPs) in small and medium-sized companies. These aspects are considered important because they guarantee the adequate quality control on raw materials and processed foods.

This review article gathers the major shortcomings of quality control within the Brazilian fruit pulp production sector. Moreover, the most important aspects for obtaining innocuous and nutritious fruit pulps to meet consumer expectations are also outlined.

\section{FRUIT MARKET AND FRUIT PULP PRODUCTION}

Brazil produces a wide diversity of tropical, subtropical and temperate fruits due to its continental dimensions and variety of climates. Brazil also presents regional productions specialized in certain types of fruits ${ }^{3}$.

Brazil is the third world's largest fruit producer with an annual production of 42,416 million tons in 2012, after China and India. Unprocessed fresh fruits accounts for $53 \%$ of the total commercial Brazilian fruit production, of which $3 \%$ is used to supply the international market. Of the total amount of fresh fruits $47 \%$ is processed by the national food industry. This means that $71 \%$ of total Brazilian fruit production is consumed by the domestic market, while the remaining $29 \%$ is exported to abroad 4.

European Union and United States are the main purchasers of Brazilian fruits and their derivative products. According to the Brazilian Fruit Institute (IBRAF), 759,400 and 2,149,800 tons of fresh and processed fruits, respectively, were exported in 2010, with focus on tropical fruits, whose sensorial acceptance and production have been continuously increasing in the past two decades.

Pulp and juice processing are important agro-industrial activities for the food production sector as they add economic value to fruits, avoid fruit wasting and minimize losses during commercialization of unprocessed fresh fruits. Pulp and juice processing also constitute an alternative way by which fruit growers sell their products.

One advantage of industrializing fruit pulp is the consumption of fruits native to particular regions throughout the country, some of which being highly coveted on the international market ${ }^{5}$. Fruit pulps could also supply the food industry for 
Tropical fruit pulp: main parameters to control

producing juices, ice creams, candies and confectionery and dairy products such as yogurts ${ }^{6}$. The markets of concentrated juice and pulp are notably relevant because they seek to attract consumers fundamentally by the idea of fruit nutritional value preservation ${ }^{7}$.

Preserving highly perishable fruits constitute a big challenge for agro-industries. These industries have been focused mainly on processing methods that conserve the physical structure and the nutritional and sensory attributes of fruits. Agro-industries have also been focused on expanding the consumer market of fruit pulps. Nevertheless, the lack of standard procedures within the fruit processing sector, from the farm to the final consumer, is among the major shortcomings to be overcome by fruit pulp agro-industries ${ }^{8}$.

\section{FRUIT PULP PROCESSING AND ASPECTS FOR QUALITY MAINTENANCE}

Postharvest loss is an important shortcoming for fruit pulp production because certain fruits remain alive after they are harvested. This implies that specific procedures and recover methods must be adopted in order to extend fruit shelf-life and use surplus production. These measures are taken according to the fruit type, which helps defining the best ways to handle fresh fruits during harvest, transportation, storage and commercialization.

Climacteric fruits, such as peach, apple, mango, guava, passion fruit, among many others, can be harvested when they reach the physiological maturation point, i.e., when they reach an ideal size and format, even if they are not ready for consumption. In this sense, climacteric fruits are suitable for industrialization because they provide higher uniformity in the maturation process. On the other hand, non-climacteric fruits, such as orange, lemon, pineapple and grape, do not have the ability to reach attributes that are typical of ripe fruits (sweetness, color, and acidity) after harvesting. In this case, non-climacteric fruits must be harvested only when they are completely ripened.

Consumption of fruit pulp and juice is rising continuously due to the consumer preference for healthy eating habits. Advances on food technology have enabled successful fruit processing and pulp freezing storage in appropriate packages within the food industry. Commercialization of frozen fruit pulps also make possible consumption of fruits little known, which have already attracted interest from the international market, especially those from Cerrado, North and Northeast regions of Brazil ${ }^{9}$.

Fruit pulp production line normally embraces the following steps: reception, weighing, pre-selection, washing and sanitization, pulping, packaging and freezing. In general, fruits are frozen when there is insufficient amount of fruit to be pulp, whereas unripe fruits are cooled after the washing/sanitization step. The flowchart in Figure 1 illustrates the overall process that should be adopted in order to manufacture good quality fruit pulps. Pre-selection/selection of fruits, washing and sanitization, cooling or freezing are the most important steps and must be efficiently performed ${ }^{10}$. 


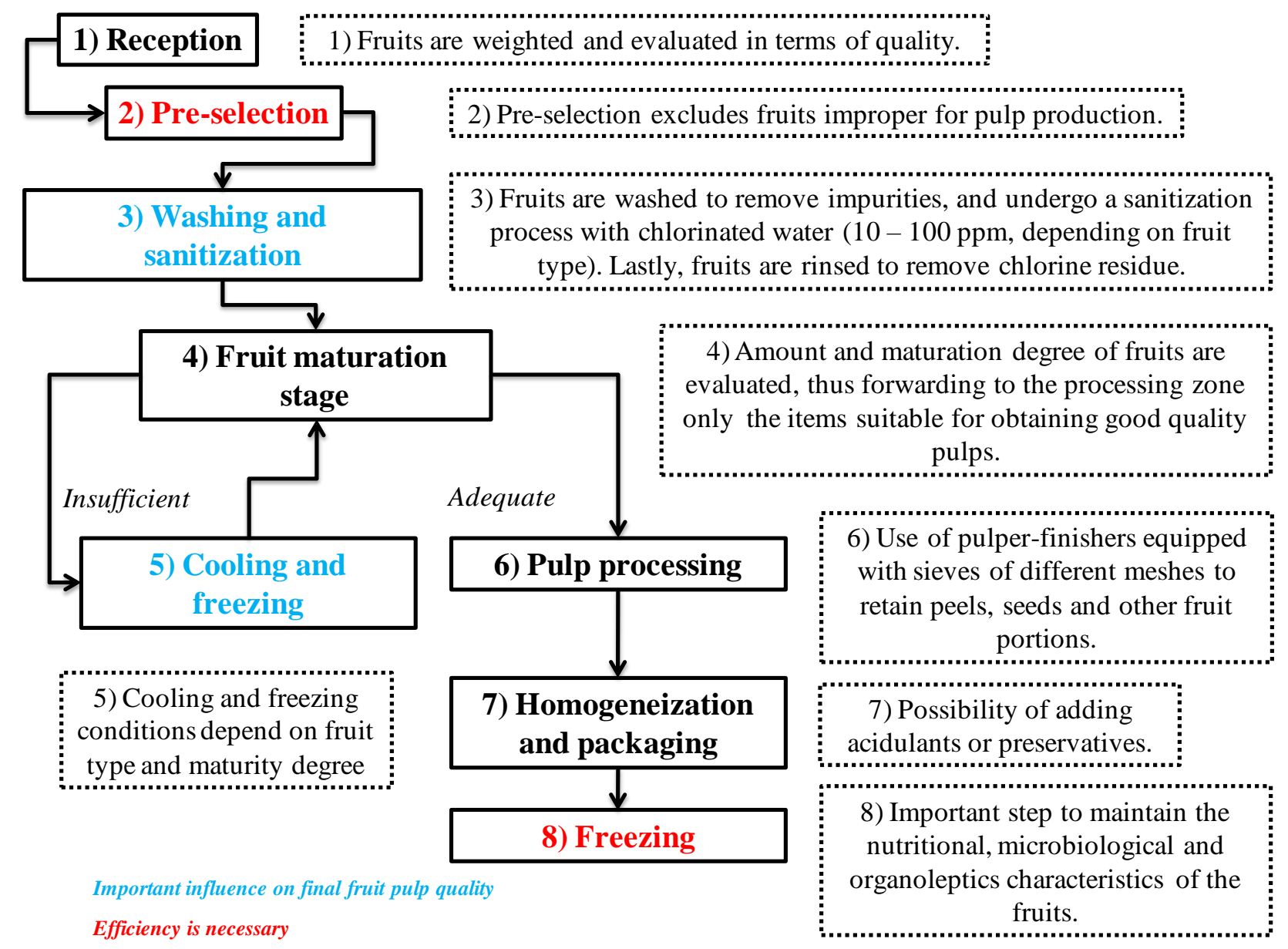

Figure 1 - Fruit pulp processing flowchart.

For small and micro-sized agro-industries, harvesting fruits at the maturation point is the most recommended practice. The maturation point is commonly referred to as firm ripe or "turning", which means that fruits will rapidly attain the maturation degree suitable for processing. A number of parameters defined by law, including physiological maturation (if the fruit is climacteric or non-climacteric), $\mathrm{pH}$, soluble solid content ( ${ }^{\circ}$ Brix) and acidity, should be determined still in field in order to harvest fruits with characteristics apposite for processing ${ }^{11,12}$. After harvesting, fruits must be suitably transported and handled to avoid mechanical injuries, heating and accumulation of metabolites ${ }^{13}$.

The reception step consists in receiving, weighing and pre-selecting fruits, thus avoiding entrance of unsuitable fruits within the processing line and improving the final product quality. Fruit pre-selection should be conducted efficiently in order to remove physically damaged, dirty or completely decayed fruits which could spoil the final product.

Storing insufficient amounts of ripe fruits for processing should be preferably done after the sanitization step. Cleaned fruits can be organized into plastic boxes and stored under refrigeration or in ventilated and little humid areas for preventing rodent attacks and proliferation of molds and insects.

Cleaning and sanitization are different steps although they are fundamental for removing microbial load from fruits. Cleaning usually consists in washing fruits with water to eliminate impurities and part of the microbial load brought from plantations, whereas sanitization is generally carried out with chlorine-based substances. 
Tropical fruit pulp: main parameters to control

Sodium hypochlorite is one of the most popular chlorine-based sanitizers whose antimicrobial activity is rather widespread ${ }^{14,15}$. When sodium hypochlorite is dissolved in cold water, it reacts to form hypochlorous acid, which is a strong oxidizing agent that is effective against foodborne pathogens ( $S$. aureus, $L$. monocytogenes and E. coli). Hypochlorous acid serves to disinfect surfaces, fruits and vegetables, by killing suspended and film-forming microorganisms ${ }^{16-19}$.

Fruit immersion into sodium hypochlorite solution is usually performed for $15 \mathrm{~min}$, using concentrations between 20 and $100 \mathrm{ppm}$ to reduce the microbial load to permissible levels. Long-term usages of sodium hypochlorite solution should be previously tested due to the time-dependent chlorine degradation. Fruits must be subsequently rinsed in order to remove hypochlorite residue (Table 1).

Table 1 - Initial sodium hypochlorite concentration and residual chlorine concentration after sanitization (15 min) of some tropical fruits.

\begin{tabular}{lll}
\hline Fruit & Initial Concentration (ppm) & Residual Concentration (ppm) \\
\hline Pineapple & 30 & 25 \\
Acerola & 90 & 20 \\
Hog plum & 70 & 10 \\
Cashew & 80 & 10 \\
Guava & 50 & 25 \\
Soursop & 20 & 10 \\
Mango & 50 & 20 \\
Passion fruit & 30 & 20 \\
Umbu & 80 & 10 \\
Umbu-hog plum & 80 & 10 \\
\hline
\end{tabular}

Sodium hypochlorite is advantageous over various sanitizers due to its low cost, easy storage when produced in situ, disinfection efficiency similar to that of chlorine gas, and can remain at residual concentration. On the other hand, sodium hypochlorite is toxic and corrosive, especially at high concentrations. It also tends to decompose in contact with air, spreading chlorine gas which is toxic.

The chlorine antimicrobial activity efficiency is influenced by:

- Presence of organic matter: Organic materials such as food residue decrease the chlorine antimicrobial activity. Thus, fruits must be previously cleaned to attain a proper sanitization efficiency;

- Chlorinated solution pH: pH affects microbial activity. The highest chlorine antimicrobial activity occurs at pH 6.5 - 7.0 because hypochlorite is highly unstable at $\mathrm{pH}$;

- Temperature: Sanitizers often exhibit synergistic effect with temperature. However, chlorinated compounds decompose into chlorine gas at elevated temperatures, in addition to increasing their corrosive potential over heating;

- Concentration: As aforementioned, chlorine levels of 20 and 200 ppm are used to sanitize fruits and processing, which must be washed afterwards to remove the chlorinated solution residue;

- Contact time: Fruit sanitization with sodium hypochlorite is efficiently attained within $30 \mathrm{~min}$. Longer treatments should be avoided because the chlorine corrosive potential increases significantly over time ${ }^{20}$.

The water used in the fruit sanitization step must present physical, chemical and microbiological qualities in consonance with the ordinance 2914 of December 12, 2011 of the Brazilian Ministry of Health. These quality aspects include absence of dirties and fecal coliforms and Salmonella (in $100 \mathrm{~mL}$ ), reduced number of heterotrophic bacteria, appropriate $\mathrm{pH}$ and turbidity. Sanitization water must also contain sodium hypochlorite at concentrations between $0.2-2.0 \mathrm{ppm}$, or chlorine 
dioxide at a minimum level of $0.2 \mathrm{ppm}$ throughout all water distribution system in order to warranty the use of disinfected water in fruit sanitization ${ }^{21}$.

According to the ordinance CVS 6-99 of the Health Surveillance Center of São Paulo Secretary of Health, the chemicals and their final concentrations authorized for food sanitization are listed below:

- Sodium hypochlorite at $2.0-2.5 \%$, to obtain concentrations from 100 to 250 ppm;

- Sodium hypochlorite at $1 \%$, to obtain concentrations from 100 to $250 \mathrm{ppm}$;

- Organic chlorine at $100-250 \mathrm{ppm}$.

Controlling the sanitization process by proper adjustment of the active chlorine concentration is important to ensure not only elimination of microbial load, but also to preserve fruit organoleptic attributes. Sanitization of surfaces, machines and tools with chlorinated solutions $100-200 \mathrm{ppm}$ and subsequent rinsing should also be performed before and after fruit pulp processing.

Fruits must be separated according to their maturation degree. Unripe fruits must be stored under adequate temperature and relative humidity in order to control the ripening process and extend their shelf-life. This preserves the physical and sensory characteristics of fruit pulps.

According to the ordinance CVS 6-99 of the Health Surveillance Center of São Paulo Secretary of Health, perishable food storage has to meet the following temperature criteria:

- Frozen foods: $-18^{\circ} \mathrm{C}$ with tolerance of up to $-12{ }^{\circ} \mathrm{C}$;

- Cooled foods: $6-10^{\circ} \mathrm{C}$, or in conformity with supplier's specifications;

- Refrigerated: up to $6^{\circ} \mathrm{C}$, with tolerance of $7^{\circ} \mathrm{C}$.

Storage chamber temperature should be ideally monitored by charts displaying inferior and superior temperature limits (Figure 2). In this way, the storage chamber is operated most of the time within the permitted temperature range. Points that lie outside the limits can also be identified.

\section{Chamber - Fruit Pulp Freezing}

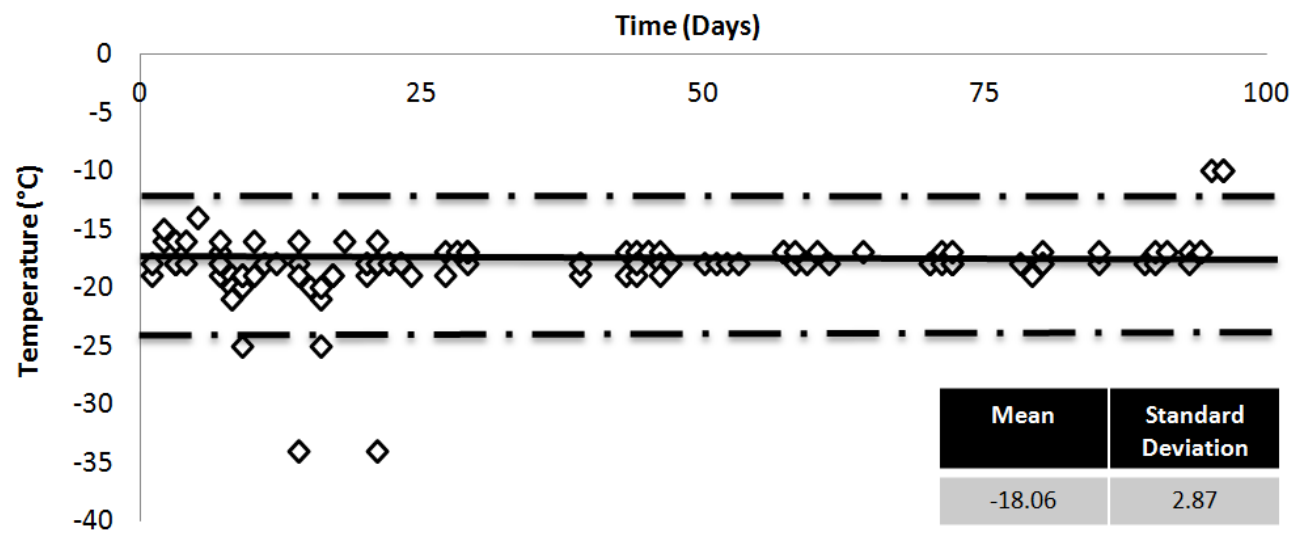

Figure 2 - Chamber temperature monitoring chart.

Fruit freezing must be performed as rapidly as possible in order to maintain the fresh fruit attributes. The usual freeze temperature range is between -12 and $-23{ }^{\circ} \mathrm{C}$. From chemical and technical points of view, the ideal temperature is $-18{ }^{\circ} \mathrm{C}$ and this should be held constant throughout the freezing step. The cooling times to reach -5 ${ }^{\circ} \mathrm{C}$ and $-18{ }^{\circ} \mathrm{C}$ should not be longer than 8 and $24 \mathrm{~h}$, respectively ${ }^{22}$.

Fruit pulp processing is carried out with the aid of pulper-finishers containing sieves with different apertures to separate peels, seeds and fibers from pulp. Fruit pulping should be performed continuously (all raw materials must be separated for 
Tropical fruit pulp: main parameters to control

continuous processing, while the packaging sector has to be prepared to receive the pulp) and rapidly, because the cooling and freezing times directly influence on the fruit pulp quality. Hand peeling, such as that used for pineapple and soursop, is another important aspect of pulp processing because food handlers contact directly internal portions of fruits. This requires maximum personal hygiene and sanitized premises. Hand peeling also constitutes a time-consuming additional stage of the fruit pulp production with high probability of microbial spoilage and fruit oxidation (nutrient and color losses).

The homogenization stage is ideally performed by coupling the pulper-finishers to the homogenization tank and packing machine, so that exposition of fruit pulp to light, air, and processing environment is efficiently avoided. Food preservatives are generally added to fruit pulps at the homogenization stage to increase consumer acceptance or extend their shelf-life.

The normative instruction No 01, 2000, of the Brazilian Ministry of Agriculture, Livestock and Supply (MAPA) defines that fruit pulps used in beverage industrialization are permitted to contain chemical additives, such as acidulants (acidity regulators), synthetic preservatives, and natural colorants, at concentrations equivalent to those allowed for fruit juices, with some specific exceptions.

The use of food preservatives aims to prevent fruit pulps from oxidation and microbial spoilage. Citric acid and sodium benzoate are among the most used food additives; the first one is used as an acidulant in sufficient amounts, while the latter is used as a preservative at maximum concentration of $1 \mathrm{~g}$ per $\mathrm{kg}$ or $\mathrm{L}$ of product. These limiting concentrations are listed in the resolution RDC No. 8 March 6, 2013, which establishes food additives permitted in fruits, vegetables and mocotó jelly.

Acidulants are added to food products with the purpose of intensifying their sour attribute. Citric acid is the most used acidulant in the food industry due to:

- Versatile applications, including "flavouring" (taste and aroma) to synergy with antioxidant compounds, in addition to controlling $\mathrm{pH}$.

- Easy obtaining (fermentation with Aspergillus niger).

- Relatively low cost ${ }^{23}$.

Although citric acid is highly compatible with most fruits, its usage as an acidulant should not be generalized. Citric acid may affect fruit sensory attributes, for example, in the case of pineapple. Ascorbic acid is considered more suitable than citric acid for acerola, soursop and cashew. Lemon juice is recommended for pineapple and hog plum fruits. In the case of passion fruit, the use of acidulants is not recommended due to the high acidity of this fruit ${ }^{24}$.

Benzoic acid and its derivatives, such as sodium benzoate, are efficient in controlling growth of yeasts and molds at $\mathrm{pH}$ range 2.5 - 4.0, over which they occur predominantly in a chemically dissociated form. Sodium benzoate is a microbiostatic agent that exhibits temporary activity on microorganisms. It is compatible with fruit pulps, whose shelf-life is no longer than 45 days, but for durable food products sodium benzoate must be used in conjunction with other antimicrobial agents. The maximum sodium benzoate concentration authorized in fruit juices and pulps is 1000 $\mathrm{ppm}$, which is not deleterious to human health, being excreted as hippuric acid after reacting with glycine ${ }^{25}$.

Fruit pulp quality inspection takes into account the standard microbiological and physico-chemical parameters for fruit pulps. Microbiological parameters are defined by product class (fruit-derived consumer goods, for instance), whereas physicochemical parameters are specifically defined by fruit type because of the peculiar characteristics of each fruit ${ }^{12}$.

In Brazil, microbiological quality of commercial fruit pulps is mainly legislated by the resolution RDC No 12, 2001, of ANVISA which approves technical regulation 
on the microbiological standards for foods ${ }^{26}$ and the normative instruction No 12 , 1999, of MAPA which legislates the quality parameters of fruit pulps ${ }^{11}$. The MAPA's normative instruction No 1, 2000, determines the main standardized physico-chemical parameters of fruit pulps with basis on acidity, total soluble solid content ( $\left.{ }^{\circ} \mathrm{Brix}\right), \mathrm{pH}$, total solids content, total natural sugar content, and vitamin $\mathrm{C}$ content. This normative instruction defines fruit pulp as a non-fermented, nonconcentrated and undiluted product obtained from pulpy fruit crushing ${ }^{12}$.

The microbial load in fruit-derived products is normally an outcome of raw material conditions and washing step efficiency, in addition to the hygienic-sanitary conditions of food handlers ${ }^{27}$. Microbiological parameters are important food quality aspects because they allow evaluating food products in relation to processing conditions, storage, distribution, shelf-life and risk to public health ${ }^{28}$.

Reaching high fruit pulp quality standards requires effective hygienic conditions from the production stage until commercialization. This also involves control on raw materials, industrial processing, transport and storage. Inside a processing plant, there must exist proper maintenance of equipment, water supply network, sewage network and electricity, as well as a correct stock flux. Training and ongoing supervision of food handlers by competent professionals is also indispensable because all activities are always performed by a considerable number of employees 29

Fruit pulp obtaining is a basic physical extraction process with possible addition of food preservatives and acidulants. Therefore, the final pulp quality will be highly dependent on the fresh fruit characteristics. In this context, fruit integrated production (FIP or PIF in portoghese) is a program that was developed in collaboration with MAPA to evaluate adequacy of fruit-derived products. FIP is based on four pillars: Production basis organization, system sustainability, and process and information monitoring (Figure 3). The main purpose of FIP is to monitor increases in the Brazilian fruit agribusiness exportation and Brazilian fruit quality. The application of natural resources with focus on environmental conservation and agriculture sustainability is the principal operation strategy of FIP. This has been implemented through systematic evaluation of fruit production with periodic monitoring, use of integrated pest management (IPM) techniques, reduction of pollutant inputs to ensure diversity and equilibrium to agro-ecosystems, and to ensure adequate and safe working conditions to employees ${ }^{30}$.
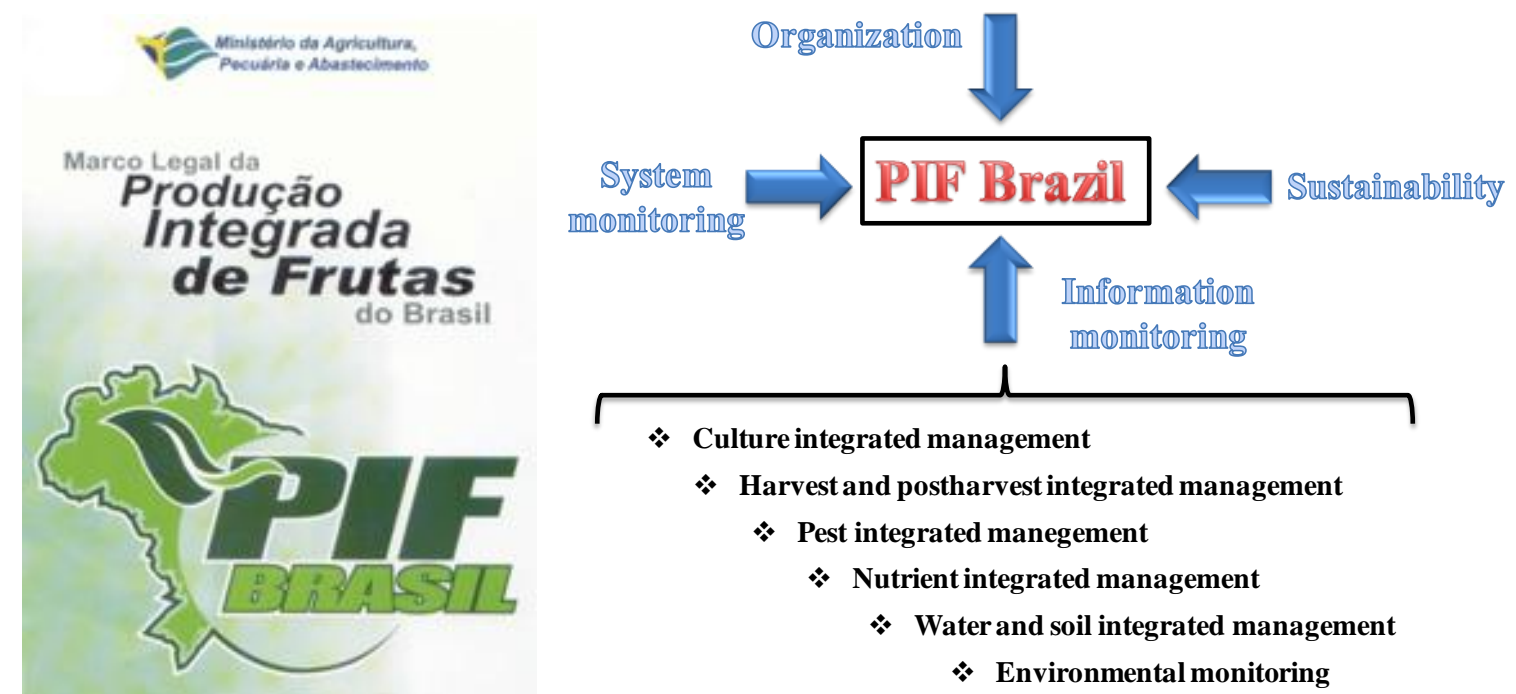

Figure 3- Fruit integrated production scheme. Source: Adapted from EMBRAPA ${ }^{30}$. 
Standard conformity seals containing numeric codes have served to validate food products as FIP, and also to track information on their origin and management procedures (pests, diseases, etc.). Consequently, there is a possibility of inspecting the conditions by which fruits were produced, transported, processed and packed, thus identifying fruit pulps since the production source until the final commercialization ${ }^{8}$. FIP program helps the food industry obtain good quality fruits suitable for pulp production.

\section{IDENTITY AND QUALITY STANDARDS (IQSs) FOR FRUIT PULPS}

The RDC No. 12, 2001, of ANVISA and the normative instructions (IN) No. 12, 1999 and IN No. 01, 2000, of MAPA are the main legislations on identity and quality standards (IQSs) of fruit pulps. The underlying purpose of an IQS is to protect consumers. Food IQSs can be used to prevent diseases transmission, restrict sale of fraudulent products and simplify purchase and sale of certain food products 31 .

In relation to microbiological analyses, the ANVISA legislation DRC No. 12, 2001, recommends a limit of $10^{2}$ fecal coliforms (MPN/mL) and absence of Salmonella in $25 \mathrm{~g}$ of pulp. The MAPA IN No. 12, 1999, recommends limits of $5.10^{3} \mathrm{CFU} / \mathrm{g}$ for molds and yeast, and $1 \mathrm{NMP} / \mathrm{g}$ for fecal coliforms. The limit value of yeasts and molds for chemically conserved or thermally treated fruit pulps changes to $2.10^{3}$ $\mathrm{CFU} / \mathrm{g}$ according to the same legislation.

Regarding physico-chemical analyses of fruit pulps, including acidity, $\mathrm{pH},{ }^{\circ} \mathrm{Brix}$, total solid content, total sugar content and vitamin $\mathrm{C}$ content, the Brazilian legislation establishes minimum required standards which depend on the fruit type ${ }^{12}$. Table 2 summarizes quality standards of some tropical fruits produced at the Brazilian northeast region that are widely accepted in the national market.

Table 2 - Identity and quality parameters (IQP) of tropical fruits.

\begin{tabular}{|c|c|c|c|c|c|c|}
\hline Fruits & $\begin{array}{ll}\text { TSS } & \left({ }^{\circ} \text { Brix }\right) \\
20^{\circ} \mathrm{C} & \end{array}$ & $\begin{array}{l}\text { Acidity } \\
\text { (g citric acid/100 g) }\end{array}$ & $\mathbf{p H}$ & $\begin{array}{l}\text { Vitamin C } \\
(\mathrm{mg} / 100 \mathrm{~g})\end{array}$ & $\begin{array}{l}\text { Total natural sugars } \\
(\mathrm{g} / 100 \mathrm{~g})\end{array}$ & Total solids (g/100g) \\
\hline Acerola & $\geq 5.5$ & $\geq 0.80$ & $\geq 2.8$ & $\geq 800.0$ & $4.0-9.5$ & $\geq 6.5$ \\
\hline Pineapple & $\geq 11.0$ & $\geq 0.30$ & - & - & $\leq 17.0$ & $\geq 14.0$ \\
\hline Cocoa & $\geq 14.0$ & $\geq 0.75$ & $\geq 3.4$ & - & $10.0-19.0$ & $\geq 16.0$ \\
\hline Hog plum & $\geq 9.0$ & $\geq 0.90$ & $\geq 2.2$ & - & $\leq 12.0$ & $\geq 9.5$ \\
\hline Cashew & $\geq 10.0$ & $\geq 0.30$ & $\leq 4.6$ & $\geq 80.0$ & $\leq 15.0$ & $\geq 10.5$ \\
\hline Guava & $\geq 7.0$ & $\geq 0.40$ & $\geq 3.5$ & $\geq 40.0$ & $\leq 15.0$ & $\geq 9.0$ \\
\hline Soursop & $\geq 9.0$ & $\geq 0.60$ & $\geq 3.5$ & $\geq 10.0$ & $\overline{6} .5-17.0$ & $\geq 12.5$ \\
\hline Papaya & $\geq 10.0$ & $\geq 0.17$ & $\geq 4.0$ & - & $\leq 14.0$ & $\geq 10.5$ \\
\hline Mango & $\geq 11.0$ & $\geq 0.32$ & $3.3-4.5$ & - & $\leq 17.0$ & $\geq 14.0$ \\
\hline Mangaba & $\geq 8.0$ & $\geq 0.70$ & $\geq 2.8$ & - & $\leq 8.5$ & $\geq 10.0$ \\
\hline Passion fruit & $\geq 11.0$ & $>2.50$ & $2.7-3.8$ & - & $\leq 18.0$ & $\geq 11.0$ \\
\hline Melon & $\geq 7.0$ & $\geq 0.14$ & $\geq 4.5$ & - & $\leq 12.0$ & $\geq 7.5$ \\
\hline Pitanga & $\geq 6.0$ & $\geq 0.92$ & $2.5-3.4$ & - & $\leq 9.5$ & $\geq 7.0$ \\
\hline
\end{tabular}

It is worth mentioning that many tropical fruit pulps highly valued in the Brazilian market do not have identity and quality standards yet, for example umbu, tamarind, sapodilla, and genipap. This hinders the requirement for control parameters and quality adjustment for these fruit pulps.

\section{Problems on physico-chemical standards of fruit pulps}

Table 3 compares some physico-chemical data of tropical fruit pulps already published in literature. The largest discrepancies between the physico-chemical parameters and the decreed values are observed for total soluble solid content ( ${ }^{\circ}$ Brix), total titratable acidity ( $\mathrm{g}$ citric acid/100 g) and vitamin $\mathrm{C}$ content. 
The main variables affecting the total soluble solid content of fruit pulps are the rainfall regime during harvest season and fruit maturation degree. These natural problems indicate wrong cultivation or harvest management. They are also associated with poor quality raw materials and pulp dilution (water addition), which is a common practice justified by some producers as a way to improve the pulping step efficiency.

Table 3 - Summary of published studies on physico-chemical analysis of tropical fruit pulps.

\begin{tabular}{llll}
\hline Reference & Fruit & \multicolumn{1}{c}{$\begin{array}{l}\text { Place/Additional } \\
\text { information }\end{array}$} & Main reported irregularities \\
\hline 31 & $\begin{array}{l}\text { Acerola, pineapple, } \\
\text { hog plum and cashew }\end{array}$ & $\begin{array}{l}\text { Campina Grande (PB), four } \\
\text { brands were studied with } 24 \\
\text { samples }\end{array}$ & $\begin{array}{l}\text { There was disagreement in relation to the law in } \\
44 \% \text { of the samples, specifically TTA for hog } \\
\text { plum, SST for acerola, cashew and total sugar } \\
\text { content for all acerola samples. }\end{array}$ \\
\hline 10 & $\begin{array}{l}\text { Pineapple, acerola, hog } \\
\text { plum, cashew, soursop, Alagoas, samples from one } \\
\text { mango and passion } \\
\text { fruit }\end{array}$ & $\begin{array}{l}\text { TSS and TS for mango, cashew and soursop } \\
\text { pulps, TS for hog plum and acerola pulp (70\% } \\
\text { of all samples). }\end{array}$
\end{tabular}

\begin{tabular}{|c|c|c|c|}
\hline 19 & $\begin{array}{l}\text { Pineapple, plum } \\
\text { acerola, cashew, guava, } \\
\text { soursop, mango, } \\
\text { mangaba, passion fruit, } \\
\text { pitanga and mandarin }\end{array}$ & $\begin{array}{l}\text { Alagoas, samples from one } \\
\text { brand but from } 3 \text { different lots }\end{array}$ & $\begin{array}{l}\text { The most irregular samples were pineapple, } \\
\text { plum, cashew, guava and passion fruit pulps, } \\
\text { representing } 45 \% \text { of pulps unsuited for IQSs. }\end{array}$ \\
\hline 36 & $\begin{array}{l}\text { Pineapple, acerola, } \\
\text { cocoa, guava }\end{array}$ & $\begin{array}{l}\text { Itapetinga (BA), two brands } \\
\text { were studied }\end{array}$ & All pulps were in conformity with IQSs. \\
\hline 37 & Mango & $\begin{array}{l}\text { Zona da Mata (MG), one } \\
\text { brands were studied }\end{array}$ & $\begin{array}{l}\text { None. All samples were in accordance with the } \\
\text { law. }\end{array}$ \\
\hline 38 & Acerola, passion fruit & $\begin{array}{l}\text { Belo Horizonte (MG), pulp } \\
\text { produced in laboratory from } \\
\text { fruits purchased from central } \\
\text { market }\end{array}$ & TTA for acerola pulps. \\
\hline 39 & $\begin{array}{l}\text { Hog plum, guava, } \\
\text { mango and umbu }\end{array}$ & $\begin{array}{l}\text { Reconcavo Baiano (BA), Pulps } \\
\text { from four different brands } \\
\text { were studies }\end{array}$ & $\begin{array}{l}\text { TSS and vitamin C content of mango and guava } \\
\text { pulps (around } 15 \% \text { of all samples). }\end{array}$ \\
\hline 40 & Hog plum and mango & $\begin{array}{l}\text { Teresina (PI), five brands were } \\
\text { studied }\end{array}$ & $\begin{array}{l}\text { Irregularities in } 60 \% \text { and } 20 \% \text { of hog plum pulp } \\
\text { regarding TSS and TTA, respectively. } \\
\text { Irregularities in } 20 \% \text { and } 40 \% \text { of mango pulp } \\
\text { regarding moisture content and pH. }\end{array}$ \\
\hline 41 & $\begin{array}{l}\text { Acerola, hog plum and } \\
\text { cashew }\end{array}$ & $\begin{array}{l}\text { Ceará and Rio Grande do } \\
\text { Norte states, } 45 \text { samples were } \\
\text { studied }\end{array}$ & $\begin{array}{l}\text { Many samples were not in accordance with the } \\
\text { law, especially in terms of TSS (about } 50 \% \text { of } \\
\text { samples), TTA (about } 55 \% \text { of samples) and } \\
\text { vitamin C ( } 25 \% \text { of samples, mainly acerola } \\
\text { pulps). }\end{array}$ \\
\hline 42 & $\begin{array}{l}\text { Acerola, hog plum and } \\
\text { cashew }\end{array}$ & $\begin{array}{l}\text { Pernambuco and Paraiba } \\
\text { states, } 71 \text { samples were studied } \\
\text { with about } 45 \% \text { of the pulp } \\
\text { industries located in both states }\end{array}$ & $\begin{array}{l}\text { Irregularities mainly related to TSS, TTA and } \\
\text { vitamin C content in } 68.2 \% \text { of hog plum pulps, } \\
59.1 \% \text { of cashew pulps and } 40.7 \% \text { of acerola } \\
\text { pulps. }\end{array}$ \\
\hline 43 & $\begin{array}{l}\text { Acerola, cashew and } \\
\text { passion fruit }\end{array}$ & $\begin{array}{l}\text { Médio Norte (MT), four } \\
\text { different brands were studies: } \\
\text { two brands from Mato Grosso } \\
\text { states and two brands from } \\
\text { Bahia and Parana states. }\end{array}$ & $\begin{array}{l}\text { TTA, TSS and TS of more than } 50 \% \text { of samples } \\
\text { were below the values determined by law. }\end{array}$ \\
\hline 44 & Cashew and soursop & $\begin{array}{l}\text { Viçosa (MG), three brands } \\
\text { were studies }\end{array}$ & $\begin{array}{l}\text { SST below the minimum requirement in } 33.3 \% \\
\text { of cashew pulps and } 66.66 \% \text { of soursop pulps. }\end{array}$ \\
\hline 45 & Passion fruit & $\begin{array}{l}\text { Bauru (SP), } 25 \text { samples from } 7 \\
\text { different brands were studies }\end{array}$ & $\begin{array}{l}44 \%, 12 \% \text {, and } 8 \% \text { of all samples do not meet } \\
\text { the minimum requirements for STT, TTA and } \\
\text { pH, respectively. }\end{array}$ \\
\hline 46 & $\begin{array}{l}\text { Pineapple, Acerola, } \\
\text { soursop and mango }\end{array}$ & $\begin{array}{l}\text { Interior, Ceará, samples from } \\
\text { two small companies }\end{array}$ & $\begin{array}{l}\text { TTA for soursop pulp, and TSS for acerola, } \\
\text { soursop, and mango pulps. }\end{array}$ \\
\hline 47 & Acerola and hog plum & $\begin{array}{l}\text { Maceió, (AL), samples from } \\
\text { one brand }\end{array}$ & $\begin{array}{l}\text { None in terms of legislation on TTA, } \mathrm{pH} \text { and } \\
\text { vitamin } \mathrm{C} \text { content. }\end{array}$ \\
\hline
\end{tabular}


Tropical fruit pulp: main parameters to control

Diluting fruit pulps to reduce the total solid content ( $\left.{ }^{\circ} \mathrm{Brix}\right)$ to minimum levels required by the Brazilian legislation is a fault, since the law states that "fruit pulp is an unfermented, not concentrated and undiluted product obtained from pulpy fruits by a technical process and with a minimum total solid content from the fruits edible portion" 12 .

The discrepancies of acidity and vitamin $\mathrm{C}$ content among the published data are mainly ascribed to the low quality of the fruits used to produce pulps, thus indicating fruit deterioration. Fruits improper to be eaten fresh due to complete decaying, mechanical injuries and deformations or breakage during transport are often used in pulp production.

It is worth pointing out that every activity, from postharvest to fruit processing, affects the phytochemicals and antioxidant properties of fresh fruits, the latter related to bioactive compounds beneficial to human health, such as vitamins $\mathrm{C}$ and $\mathrm{E}$, carotenoids and polyphenols ${ }^{32}$. In this context, the determination of vitamin $\mathrm{C}$ content in fruits is very important because vitamin $\mathrm{C}$ degradation favors the appearance of non-enzymatic browning and bitter taste in fruit pulps ${ }^{33}$. Furthermore, vitamin $\mathrm{C}$ is an important food quality indicator due to its thermolabile nature. The presence of vitamin $\mathrm{C}$ in foods may lead to believe that other food nutrients are also preserved ${ }^{33,34}$. The processing method, storage condition, packaging, exposure to oxygen, light, and metallic catalysts, initial vitamin $\mathrm{C}$ content, and microbial load are among the principal factors that lead to vitamin $\mathrm{C}$ degradation ${ }^{35}$.

Considering fruit pulp processing solely as a physical extraction method, the main aspects that must be controlled for pulp quality assurance are raw material quality, fruit washing/sanitization efficiency, processing time (prevent aeration or unnecessary lighting), and effective freezing procedures (observing the entire cold chain, processing, transport and sale to consumer). Campelo et al. ${ }^{48}$ observed that the vitamin $\mathrm{C}$ content of acerola pulp produced in laboratory under controlled conditions decreased by $40 \%$ after 12 -month storage. The remaining vitamin C content was still greater than the recommended daily intake (RDI), $90 \mathrm{mg} / \mathrm{day}$. The lost vitamin $\mathrm{C}$ percentage decreased when acerola pulp was pasteurized before storing. Yamashita et al. ${ }^{49}$ found that the vitamin $\mathrm{C}$ content of pasteurized acerola pulp reduced by 10 to $15 \%$ for storage times between $10-120$ days, regardless of the freezing temperature $\left(-12\right.$ and $\left.-18^{\circ} \mathrm{C}\right)$. On the other hand, fresh acerola fruits lost between 20 and $40 \%$ of vitamin $\mathrm{C}$ depending on the freezing temperature, with best vitamin $\mathrm{C}$ maintenance occurring at $-18^{\circ} \mathrm{C}$. Heat treatments involving temperatures above $60^{\circ} \mathrm{C}$ are able to inactivate enzymes. Therefore, vitamin $\mathrm{C}$ oxidation occurs throughout the exhaustion and pasteurization steps, but the remaining content becomes more stable after pasteurization due to enzyme inactivation ${ }^{50}$.

In relation to acidity and $\mathrm{pH}$ analyses, Chitarra \& Chitarra ${ }^{51}$ reported that the ability to regulate some fruit derivatives can lead to broad variations in acidity without affecting $\mathrm{pH}$, even though small $\mathrm{pH}$ variations interfere on the organoleptic characteristics of fruit pulps. $\mathrm{pH}$ is an important parameter because it influences directly organoleptic characteristics, microbial growth and selection of materials for the processing environment (corrosion) ${ }^{39}$.

Organic acids, which are secondary products from fruit breathing metabolism, play a direct role on the development of characteristic flavor and aroma in fruits ${ }^{42}$. Titratable acidity and $\mathrm{pH}$ measurements provide an estimative of the deterioration level of certain types of foods, which is confirmed by the development of uncommon acidity or alkalinity ${ }^{31}$. High acidity values are related to low quality raw materials and excessive addition of acidulants, whereas low acidity values are likely due to dilution of fruit pulp to obtain minimum soluble solid contents ( $\left.{ }^{\circ} \mathrm{Brix}\right)$. 
A parameter that is increasingly used to characterize fruit pulps is Ratio ${ }^{37,39,45,52}$. Ratio evaluates correctly the pulp taste, being more representative than individual measurements of sugars and acidity ${ }^{53}$. It consists of a relationship between total soluble solids content $\left({ }^{\circ}\right.$ Brix) and acidity (g/100 g) (Equation 1).

Ratio $=\frac{T S S}{T T A}$

Another fruit pulp parameter easily determined is density $(\rho)$. Equation 2 provides a relationship between density and total soluble solid content $\left(10-18^{\circ} \mathrm{Brix}\right)$ at $30^{\circ} \mathrm{C}$ with correlation factor $\left(\mathrm{R}^{2}\right)$ of 0.91 . This equation was based on analyses of acerola, cashew, soursop, mandarin and passion fruit ${ }^{54}$.

$\rho=4.4181(\mathrm{TSS})+997.61\left(\mathrm{Kg} \mathrm{m}^{-3}\right)$

Error $=1.7 \%$

\section{Problems on microbiological standards of fruit pulps}

The microbiological parameters listed in Table 4 allow concluding that the yeasts and molds counts were the most worrying index within the pulp production chain. Filamentous fungi and yeasts are the main cause of microbiological deterioration of fruit-derived products, mainly due to their growth capacity at low $\mathrm{pH}$ and anaerobiosis (yeast) ${ }^{37}$.

Low counts of yeast and mold are considered to be normal (not significant) in fresh and frozen foods. On the contrary, high counts signify microbial spoilage, which may lead to product refusal, and represent a risk to public health because some mold species produce mycotoxins ${ }^{27,55}$.

High counts of mold and yeast, with or without presence of bacterial coliforms strengthen the idea of inappropriate processing and/or post-processing contamination. This is possibly explained by the raw material quality, improper handling and dirty equipment or unsatisfactory sanitization procedures ${ }^{10,27,56-58}$.

The mammal intestinal tract contains a myriad of microorganisms, representing a major source of foodborne pathogens. In absence or poor hygiene conditions, these enteric microorganisms contaminate manipulators and, consequently, the foods prepared by them ${ }^{61}$. Enteric bacteria commonly associated with food poisoning are Salmonella sp., Shigella sp. and Escherichia coli, which belong to the coliforms group (total coliforms). This bacterial group is one of the best hygiene indicators in food processing. The fecal coliforms subgroup (commonly known as E. coli) is exclusive to mammal intestinal tract and relates specifically to total coliforms which have the ability to ferment lactose with gas production when they are incubated at 44 $-45^{\circ} \mathrm{C}^{28}$. Salmonella and Shigella, on the other hand, do not ferment lactose.

Spoilage bacteria, usually associated with genus Acetobacter, Alicyclobacillus, Bacillus, Clostridium, Gluconobacter, Lactobacillus, Leuconostoc, Saccharobacter, Zymomonas and Zymobacter, are native to fruit cultivation areas, where potentially pathogenic bacteria are nonexistent ${ }^{37}$.

Studies listed in Table 4 reveal that lack of hygiene is related to the fecal coliforms group, although these cases were identified only in a small number of samples. These results lead to infer that the major microbiological problems are associated with the amount of yeasts and molds caused by the poor quality raw materials, inefficient fruit washing/sanitization steps and improper preservation of fruit pulps. The two laws on microbiological standards for fruit pulp industry differ with respect to the microbiological parameters. While ANVISA focuses on pathogenic microorganisms, such as coliforms and Salmonella, MAPA focuses on hygiene aspects of the fruit pulp processing stages, mainly the fecal coliforms and molds and 
Tropical fruit pulp: main parameters to control

yeasts counts (common microorganism that grow very rapidly if the fruit pulp is not handled or stored properly).

Table 4 - Summary of published studies on microbiological analyses of tropical fruit pulps.

\begin{tabular}{|c|c|c|c|}
\hline Reference & Fruit & $\begin{array}{l}\text { Place/Additional } \\
\text { information }\end{array}$ & Main reported irregularities \\
\hline 37 & Mango & $\begin{array}{l}\text { Zona da Mata (MG), } \\
\text { samples from one brand }\end{array}$ & $\begin{array}{l}\text { All pulps are in conformity with standards } \\
\text { established by law. }\end{array}$ \\
\hline 60 & $\begin{array}{lr}\text { Pineapple, } & \text { acerola, } \\
\text { hog plum, } & \text { cashew, } \\
\text { guava, } & \text { soursop, } \\
\text { papaya, } & \text { mango, } \\
\text { melon, } & \text { passion } \\
\text { fruit, } & \text { siriguela, } \\
\text { umbu } & \\
\end{array}$ & $\begin{array}{l}\text { Russas (CE), } 24 \text { samples } \\
\text { provided by a local } \\
\text { medium-sized company }\end{array}$ & $\begin{array}{l}\text { Conformity with respect to coliforms counts. } 50 \% \\
\text { of samples presented counts of yeasts and molds } \\
\text { above the permitted values. Lack of sanitary control } \\
\text { and hygienic conditions during processing, } \\
\text { cleaning, selection of raw materials and storage } \\
\text { conditions. Absence of GMPs. }\end{array}$ \\
\hline 19 & $\begin{array}{l}\text { Pineapple, plum } \\
\text { acerola, hog plum, } \\
\text { guava, soursop, } \\
\text { mango, mangaba, } \\
\text { passion fruit, cherry } \\
\text { and mandarin }\end{array}$ & $\begin{array}{l}\text { Alagoas, samples from one } \\
\text { brand but from three } \\
\text { different sets }\end{array}$ & $\begin{array}{l}\text { The most irregular samples were pineapple, plum, } \\
\text { cashew, guava and passion fruit pulps constituting } \\
30 \% \text { of the pulps unfit for human consumption due } \\
\text { to excessive count of yeasts and molds. }\end{array}$ \\
\hline 27 & $\begin{array}{l}\text { Açaí, acerola, } \\
\text { bacuri, cashew, } \\
\text { cupuaçu, passion } \\
\text { fruit, tamarind and } \\
\text { murici }\end{array}$ & $\begin{array}{l}\text { Palmas (TO), samples } \\
\text { from two growers in a } \\
\text { local market }\end{array}$ & $\begin{array}{l}\text { The pulps were in conformity with standards } \\
\text { established by law with respect to total and fecal } \\
\text { coliforms, but } 29.6 \% \text { of the samples were above the } \\
\text { permitted yeasts and molds count values. }\end{array}$ \\
\hline 31 & $\begin{array}{l}\text { Pineapple, acerola, } \\
\text { hog plum, cashew, } \\
\text { guava and grape }\end{array}$ & $\begin{array}{l}\text { Campina Grande (PB) } 19 \\
\text { samples from } 3 \text { different } \\
\text { brands }\end{array}$ & $\begin{array}{l}\text { About } 31.6 \% \text { of the samples, pineapple, hog plum, } \\
\text { guava and cashew, were not in conformity with the } \\
\text { legal required standards. Contamination by yeasts } \\
\text { and molds, salmonella and coliforms. Lack of } \\
\text { sanitary control and hygienic conditions during } \\
\text { processing, cleaning, and selection of raw } \\
\text { materials. Absence of GMPs. }\end{array}$ \\
\hline 55 & $\begin{array}{l}\text { Acerola, cashew, } \\
\text { guava, mango, } \\
\text { passion fruit and } \\
\text { strawberry }\end{array}$ & Datas (MG) & $\begin{array}{l}\text { Pulps are in conformity with standards established } \\
\text { by law in relation to total coliforms and Salmonella. } \\
\text { For yeast and mold, only } 25 \% \text { of the pulps } \\
\text { presented irregularities, which indicates } \\
\text { inappropriate selection and/or processing of fruits } \\
\text { and absence of GMPs. }\end{array}$ \\
\hline 56 & $\begin{array}{l}\text { Acerola, cupuaçu, } \\
\text { guava and passion } \\
\text { fruit }\end{array}$ & $\begin{array}{l}\text { Boa Vista (RR), } 5 \text { different } \\
\text { brands }\end{array}$ & $\begin{array}{l}\text { There was irregularity in terms of molds and yeasts } \\
\text { counts in } 80 \% \text { of acerola pulps, } 64 \% \text { of cupuaçu } \\
\text { pulps, } 92 \% \text { of guava pulps and } 76 \% \text { of passion fruit } \\
\text { pulps. }\end{array}$ \\
\hline 58 & Açaí & $\begin{array}{l}\text { Pouso Alegre (MG), } 36 \\
\text { samples from } 12 \text { different } \\
\text { stores }\end{array}$ & $\begin{array}{l}\text { The microbiological quality was unsatisfactory. } \\
\text { Sanitary measures are needed to reduce } \\
\text { contamination level, such as efficient cleaning and } \\
\text { sanitizing of equipment and utensils, adequate raw } \\
\text { material and good storage conditions. }\end{array}$ \\
\hline 59 & Several fruits & $\begin{array}{l}\text { Freitas (BA), samples from } \\
5 \text { different stores }\end{array}$ & $\begin{array}{l}\text { All pulps were contaminated by molds, yeasts and } \\
\text { coliforms, but were within the legal standards, thus } \\
\text { ensuring their hygienic quality. }\end{array}$ \\
\hline
\end{tabular}

\section{GMPs, SOPs AND HACCP IN THE FRUIT PULP INDUSTRY}

This topic addresses the relationships between quality aspects and food industry legislation. Among the tools available to create these relations are good manufacturing practices (GMPs), standard operating procedures (SOPs), microbiological risk assessment (MRA), quality management (ISO series), total quality management (TQM) and hazard analysis critical control points (HACCP) ${ }^{1,62}$. The Brazilian legislation obliges GMPs for any producer or food handler. GMPs are 
considered in $77 \%$ of the national or international certification processes, of which $50 \%$ use only GMPs to certify food products. Hence, GMP compliance is considered to be a minimum procedure for obtaining safe food products ${ }^{63}$.

The most representative GMPs and SOPs texts, as well as water portability for food handling processes are described in the documents listed below:

- Ordinance No. 326 of July 30, 1997, of the Brazilian Ministry of Health, which declare a technical regulation on hygiene and sanitary conditions and good manufacturing practices for food companies;

- Ordinance No. 368 of September $4^{\text {th }}, 1997$, of the Brazilian Ministry of Agriculture, Livestock and Food Supply (MAPA), which establishes technical regulations on hygiene and sanitary conditions and good manufacturing practices for food companies;

- RDC Resolution No. 275 October 21, 2002, of the Brazilian Health Surveillance Agency (ANVISA), which provides a technical regulation on standard operating procedures and a verification service for good manufacturing practices in food companies;

- Ordinance No. 2914 of September 12, 2011, which regulates procedures to monitor quality of water for human consumption.

The GMP manual has to include all parameters and control operations used within the food industry, and their respective periodicity monitored by a technician. The manual must declare general personal hygiene and training aspects, facility project, as well as production flowchart, and pest and quality control programs. The control periodicity must be established in the eight SOPs generally required for a food processing industry:

1. Hygiene of premises, machines and tools, which define the entire cleaning management process, its maintenance, sanitizer concentration, time and periodicity.

2. Water portability, which emphasizes water standards required in all process and its portability, with periodic analyses.

3. Hygiene and health of food handlers. The conduct and physical state of food handlers are an essential aspect of food quality. This SOP emphasizes the Program for Medical Control of Occupational Health $(\mathrm{PMCOH})$, training periodicity and employees conduct required in a processing area.

4. Waste management, referring to management of residues generated in the industry.

5. Preventive maintenance and calibration of equipments, which indicates the need for maintenance of equipment and premises in the processing area.

6. Integrated management of vector and urban pests, which defines potential pests and vectors, as well as the methods and their periodicity to avoid presence of pests in the processing area.

7. Selection and reception of raw materials, packaging and ingredients. Important item that safeguards the traceability of all inputs used in fruit pulp production. This is one the most important fundaments of food product safety.

8. Food gathering program. Food companies are also responsible for withdrawal products from market if the food expiration date is exceeded. This SOP establishes the final management of unsold products.

Hazard Analysis Critical Control Points (HACCP) provides guidance on how to identify biological, chemical and physical hazards in a particular food processing line and how to control them at the Critical Control Points (CCP) throughout production ${ }^{1,64}$. Some HACCP implementation attempts in vegetal food area, such as olive oil and minimally processed vegetables, have already been published, and revealed that the use of HACCP as a control system tool is a natural trend ${ }^{65,66}$. Nevertheless, the current Brazilian legislation requires HACCP only for animal food 
Tropical fruit pulp: main parameters to control

companies, such as meat, milk, honey and their derivative products. The fruit processing industry is still exempt from HACCP, but this requirement will tend to be gradually imposed over the years.

The four actions (5S program, GMPs, SOPs and HACCP) constitute the pyramid quality basis. According to this pyramid, food product standardization recognized nationally and internationally (ISO, for example) is only accomplished when all four actions are formed and well adapted to real industrial conditions ${ }^{10}$.

Investigations aim to discover existence of hazards to health and integrity of consumers. It is performed by inspecting raw materials and all relevant production chain stages, including product consumption by consumers. These investigations are focused on:

- Microbiologically susceptible foods that favor microbial growth and toxin production;

- Pathogenic microorganisms or toxic substances;

- Inadequate heat treatment, that is, inadequate time-temperature combinations;

- Inadequate procedures after heat treatment;

- Environmental conditions that allow the transfer of pathogenic microorganisms or toxic substance to foods through air, water or other vectors ${ }^{1,10,64}$.

Microbiological analyses should be carried out in stages of sanitization, peeling, pulping, heat treatment or preservative addition and freezing, in order to minimize significant microbial proliferation or existence of physical or chemical hazards.

In general, safety management may be assumed as the sum of risks management that is usually administered by the government at a macro level. The government supervises and establishes IQSs for food products, while the food production sector executes the risk management, not only in terms of application, but also maintenance through quality tools such as GMPs, SOPs, HACCP, ISO etc. This ensures that good quality food products will be available to consumers ${ }^{63}$.

\section{CONCLUDING REMARKS}

Quality of fruit pulps involves various control aspects that must be respected in order to offer high nutritional, microbiological and sensory quality product to consumers. The increasing number of fruit pulp producers, generally represented by small groups of producers without skilled labor, constant hygiene facilities inspection, and standard pulp conservation procedures, jeopardizes the expansion of the entire Brazilian fruit pulp economy, mainly in relation to the use of fruit pulps for manufacturing other products (juices and ice creams) and exportation. Correct washing and sanitization of good quality fresh fruits may be responsible for the absence of microbial load or pathogenic microorganisms in fruit pulps. Diluting fruit pulps to increase pulp yield and adjust the minimum total soluble solid content must be abolished because it is not permitted by law, even if this procedure is justified by the decrease of pulp viscosity. Adoption of HACCP could help strengthen the microbiological control within all fruit pulp processing lines. Effective inspections on small and micro-sized companies should be adopted by governmental agencies. Data listed in this article reveal that a public health crisis in underway once fruit pulps are frequently distributed from the industries directly to markets.

\section{REFERENCES}

1 Dias SS, Barbosa VC, Costa SRR. Utilização do APPCC como ferramenta da qualidade em indústrias de alimentos. Rev. Ciênc Vida, Seropédica. 2010; 30(2): 99-111.

2 Cantillano FF, Almeida GB. Manejo e logística na colheita e pós-colheita na produção integrada de frutas no Brasil. In: Zambolim L. et al. Procedimentos de produção integrada 
de frutas: agropecuária sustentável alimentos seguros. Brasília: Ministério da Agricultura, Pecuária e Abastecimento (MAPA) e Secretaria de Desenvolvimento Agropecuário e Cooperativismo, 2009. 977-1008.

3 Agência de Desenvolvimento do Estado do Ceará. Perfil da produção de frutas Brasil Ceará. Fortaleza: ADECE Internet. 2013 cited 2015 March 20. Available from: $<$ http://www.adece.ce.gov.br/phocadownload/Agronegocio/perfil_da_producao_de_frutas_ brasil_ceara_2013_frutal.pdf>.

4 Associação Brasileira de Fruticultura. Anuário Brasileiro da Fruticultura 2014. Santa Cruz do Sul: Editora Gazeta; 2014.

5 Moraes IVM. Produção de Polpa de Fruta Congelada e Suco de Fruta. Rio de Janeiro: REDETEC (SBRT - Serviço Brasileiro de Normas Técnicas) - Rede de Tecnologia do Rio de Janeiro, 2006.

6 Dantas RL, Rocha APT, Araujo AS, Rodrigues MSA, Maranhão TKL. Perfil da qualidade de polpas de frutas comercializadas na cidade de Campina Grande/PB. Rev. Verde Agroecol. Desenv. Sustentável. 2010; 5(5): 61-66.

7 Guerra NR, Carvalho JLM, Gama MB. Coordenação da qualidade de frutas para a produçao de sucos e polpas: um estudo exploratório. In: Nordeste: Desafios do desenvolvimento para a inclusão social. Proceedings of Nordeste: Desafios do desenvolvimento para a inclusão social; 19-21 october 2011; Petrolina. Petrolina: Sociedade Brasileira de Economia, Administração e Social Rural - VI SOBER Nordeste; 2011. 1-15.

8 Vendrametto LP, Di Augustini CA, Bonilla SHA. Produção integrada de frutas no Brasil e sua interface com a produção mais limpa. In: $3^{\circ}$ International Workshop Advances in Cleaner Production: Cleaner Production Initiatives and Challenges for a Sustainable World; 18-20 May 2011; São Paulo. São Paulo: Universidade Paulista; 2011.

9 Matta VM, Freire Junior M, Cabral LMC, Furtado AAL. Polpa de fruta congelada. Brasília: Embrapa Informação Tecnológica, 2005.

10 Silva CEF, Moura EMO, Souza JEA, Abud AKS. Quality control of tropical fruit pulp in Brazil. Chem. Eng. Trans. 2015; 44: 193-198.

11 Ministério da Agricultura, Pecuária e Abastecimento (MAPA). Instrução Normativa $\mathrm{N}^{\circ}$ 12, de 10 de setembro de 1999. Padrões de Identidade e Qualidade para Polpas de Frutas Internet. 1999 cited 2015 Oct 19. Avaiable from: http://sistemasweb.agricultura.gov.br/sislegis/action/detalhaAto.do?method=gravarAtoPDF \&tipo $=I N M \&$ numeroAto=00000012\&seqAto=000\&valor Ano=1999\&orgao=MAA\&codTi po $=\&$ desItem $=\&$ desItemFim $=$

12 Ministério da Agricultura, do Abastecimento. Instrução Normativa No 01, de 07 de janeiro de 2000. Regulamento técnico geral para fixação dos padrões de identidade e qualidade para polpa de fruta Internet. 2000 cited 2015 Oct 19. Available from: http://sistemasweb.agricultura.gov.br/sislegis/action/detalhaAto.do?method=gravarAtoPDF $\&$ tipo $=I N M \&$ numeroAto $=00000001 \&$ seqAto $=000 \&$ valor $A$ no=2000\&orgao $=$ MAPA\&cod Tipo $=\&$ desItem $=\&$ desItemFim $=$.

13Tolentino VR, Silva AG. Processamento de vegetais: frutas e polpa congelada. Manual Técnico ${ }^{\circ}$. 12. Niterói: Programa Rio Rural; 2008.

14 Green DE, Stumpf PK. The mode of action of chlorine. J. Am Water Works Assoc. 1946; 38: 1301-1305.

15 Knox WE, Stump PK, Green DE, Auerbach VH. The inhibition of sulfhydryl enzymes as the basis of the bactericidal action of chlorine. J. Bacteriol. 1948; 55: 451-458.

16 Cabeça TK, Pizzolitto AC, Pizzolitto EL. Activity of disinfectants against foodborne pathogens in suspension and adhered to stainless steel surfaces. Braz J Microbiol. 2012; 43(3): 1112-1119.

17 Sun SH, Kim SJ, Kwak SJ, Yoon KS. Efficacy of sodium hypochlorite and acidified sodium chorite in preventing browning and microbial growth on fresh-cut produce. Prev. Nutr. Food Sci. 2012; 17: 210-216.

18 Lima FR, Ahmed S. Activity of disinfectants related to food hygiene and sanitation. Northern Int. Med. Coll. J., 2015; 6(2): 64-67.

19 Silva CEF, Moura EMO, Andrade FP, Góis GNSB, Silva ICC, Silva LMO, Souza JEA, Abud AKS. Importância da monitoração dos padrões de identidade e qualidade na indústria da polpa de fruta. J. Bioen. Food Sci. 2016; 3(1): 17-26. 
Tropical fruit pulp: main parameters to control

20 Eifert JD, Sanglay GC. Chemistry of chlorine sanitizers in food processing. Dairy, Food Environ Sanit. 2002; 22(7): 534-538.

21 Ministério da Saúde. Portaria N. ${ }^{\circ}$ 2.914, de 12 de dezembro de 2011. Dispõe sobre normas de potabilidade de água para o consumo humano Internet. 2011 cited 2015 Oct 19. Available http://bvsms.saude.gov.br/bvs/saudelegis/gm/2011/prt2914_12_12_2011.html

22 NPC. Produção de polpa de fruta congelada Internet. 2015 cited 2016 March 25. Available from: http://www.npcequipamentos.com.br/info_polpa_congelada.asp.

23 Macena PT, Nunes WV. Acidulantes. Food Ingredients Brasil. 2011; 19: 24-30.

24 Silva CEF, Silva ICC, Abud AKS. Acidulants in tropical fruit pulp: physicochemical and sensory changes. Chem. Eng. Trans. 2015; 44: 109-114.

25 Chipley JR. Sodium benzoate and benzoic acid. In: Davidson PM, Branen AL, editors. Antimicrobials in foods. New York: Marcel Dekker; 1993. p.11-48.

26 Agência Nacional de Vigilância Sanitária. Resolução RDC no 12 , de 02 de janeiro de 2001. Regulamento Técnico sobre padrões microbiológicos para alimentos Internet. 2001 $\begin{array}{lllll}\text { cited } 2015 & \text { Oct } & \text { Available } & \text { from: }\end{array}$ http://portal.anvisa.gov.br/wps/wcm/connect/a47bab8047458b909541d53fbc4c6735/RDC_ 12_2001.pdf?MOD=AJPERES

27 Santos CAA, Correia AFS, Carneiro SC. Avaliação microbiológica de polpas de frutas congeladas. Food Sci. Technol. 2008; 28(4): 913-915.

28 Franco BDGM, Landgraf M. Microbiologia dos alimentos. São Paulo: Atheneu, 2005.

29 Riedel G. Controle sanitário dos alimentos. 3 ed. São Paulo: Atheneu, 2005.

30 EMBRAPA. Produção integrada de frutas Internet. 2014 cited 2015 March 15. Available from: http://www.cnpuv.embrapa.br/publica/artigos/pif.html

31 Dantas RL, Rocha APT, Araujo AS, Rodrigues MSA, Maranhão TKL. Qualidade microbiologica de polpa de frutas comercializadas na cidade de Campina Grande/PB. Rev. Bras. Prod. Agroind. 2012; 14(2): 125-130.

32 Robles-Sanchez M, Gorinstein S, Martin Belloso O. Minimal processing of tropical fruits antioxidant potential and its impact on human health. Food Chem. 2007; 32(4): 227-232.

33 Alves JA, Nassur RCMR, Pires CRF, Alcantara EM, Giannoni JA, Lima LCO. Cinética de degradação de vitamina $\mathrm{C}$ em mangas 'Palmer' minimamente processadas armazenadas em diferentes temperaturas. Cienc. Agrotec. 2010; 34(3): 714-721.

34 Ozkan M, Aysegul K, Cemeraglu B. Effects of hydrogen peroxide on the stability of acid ascorbic during storage in various fruit juices. Food Chem. 2004; 88(4): 591-597.

35 Teixeira M, Monteiro M. Degradação da vitamina C em suco de fruta. Alim. Nutr. 2006; 17(2): 219-227.

36 Amorim GM, Santos TC, Pacheco CSV, Tavares IMC, Franco M. Avaliação microbiológica, físico-química e sensorial de polpas de polpas de frutas comercializadas em Itapetinga-BA. Enc. Biosfera. 2010; 6(11): 1-8.

37 Benevides SD, Ramos AM, Stringheta PC, Castro VC. Qualidade da manga e polpa da manga Ubá. Food Sci. Technol. 2008; 28(3): 571-578.

38 Sa CP, Magalhães CH, Nascimento WCA, Gonçalves CP. Caracterização físico-química de polpa de acerola, polpa de maracujá e extrato aquoso de albedo obtidos a partir de frutos de acerola (Malpighia emarginata D. C.) e maracujá (Passiflora edulis flavicarpa, Degener). In: Semana da Ciência e Tecnologia CEFET-BAMBUI; 17-21 november 2008; CEFET-BAMBUI. CEFET-BAMBUI, 2008.

39 Machado SS, Tavares JTQ, Cardoso RL, Machado CS, Souza KEP. Caracterizaçao de polpas de frutas tropicais congeladas comercializadas no Reconcavo Baiano. Rev. Cienc. Agr. 2007; 38(2): 158-163.

40 Monçao EC, Silva EF, Sousa PB, Silva MJM, Sousa MM. Avaliação físico-química e centesimal de polpas congeladas de cajá (Spondias mombin L.) e de manga (Mangifera indica L.) consumidas em teresina-PI. Proc. V CONNEPI; 17-19 november 2010; Maceió. Instituto Federal de Alagoas; 2010.

41 Oliveira MEB, Feitosa T, Bastos MSR, Freitas ML, Morais AS. Qualidade de polpas congeladas de frutas, fabricadas e comercializadas nos estados do Ceará e Rio Grande do Norte. B. CEPPA. 1998; 116(1): 13-22. 
42 Oliveira MEB, Bastos MSR, Feitosa T, Branco MAAC, Silva MGG. Avaliação de parâmetros de qualidade físico-químicos de polpas congeladas de acerola, cajá e caju. Food Sci. Technol. 1999; 19(3).

43 Paglarini CS, Silva FS, Porto AG, Santos D, Leite ALM. P.Avaliação físico-química de polpas de frutas congeladas comercializadas na região médio norte mato-grossense. Enciclopédia Biosfera. 2011; 7(13): 1391- 1398.

44 Pereira JMATK, Oliveira KAM, Soares NFF, Gonçalves MPJC, Pinto CLO, Fontes EAF. Avaliação da qualidade físico-química, microbiológica e microscópica de polpas de frutas congeladas comercializadas na cidade de Viçosa-MG. Alimentos \& Nutrição. 2006; 17(4): 437-442.

45 Raimundo K, Magri RS, Simionato EMRS, Sampaio AC. Avaliação física e química da polpa de maracujá comercializada na região de Bauru. Revista Brasileira de Fruticultura. 2009; 31(2): 539-543.

46 Silva MTM, Oliveira JS, Jales KA. Avaliação da qualidade físico-química de polpas de frutas congeladas comercializadas no interior do Ceará. Proc.V CONNEPI; 17-19 november 2010; Maceió. Instituto Federal de Alagoas; 2010.

47 Temoteo J.L.M., Gomes SEM, Silva EVL, Correia AGS, Sousa JS. Avaliação de vitamina $\mathrm{C}$, acidez e pH em polpas de acerola, cajá e goiaba de uma marca comercializada em Maceió-Alagoas. Proc. VII CONNEPI; 19-21 outubro 2012; Palmas. Instituto Federal do Piauí; 2012.

48 Campelo ECS, Martins MHB, Carvalho IT, Pedrosa EMR. Teores de vitamina 'C' em polpas de acerola (Malpighia glabra L.) congeladas. B. CEPPA. 1998; 16(1): 107-113.

49 Yamashita F, Benassi MT, Tonzar AC, Moriya S, Fernandes JG. Produção de acerola: estudo da estabilidade da vitamina C. Food Sci. Technol. 2003; 23(1): 92-94.

50 Jawaheer B, Goburdhun D, Ruggoo A. Effect of processing and storage of guava into jam e juice on the ascorbic acid content. Plants Food Hum. Nut. 2003; 58: 1-12.

51 Chitarra MIF, Chitarra AB. Pós-colheita de frutos e hortaliças: fisiologia e manuseio. Lavras: ESAL/FAESPE, 1990.

52 Tazima ZH, Neves CSVJ, Stenzel NMC, Yada IFU, Leite Junior RP. Produção e qualidade de frutos de cultivares de laranja-doce no norte do Paraná. Rev. Bras. Frut. 2009; 31(2): 474-479.

53 Pinto WS, Dantas ACVL, Fonseca AAO, Ledo CAS, Jesus SC, Calafage PLP, Andrade EM. Caracterização física, físico-química e química de frutos de genótipos de cajazeiras. Pesq. Agropec. Bras. 2003; 38(9): 1059-1066.

54 Mattos JS, Mederos BJT. Densidade de polpas de frutas tropicais: Banco de dados e determinação experimental. 2008; 2(2): 109-118.

55 Batista AG, Oliveira BD, Oliveira MA, Guedes TJ, Silva DF, Pinto NAVD. Parâmetros de qualidade de polpas de frutas congeladas: uma abordagem para produção do agronegócio familiar no Alto Vale do Jequitinhonha. Tecnol. Cienc. Agropec. 2013; 7(4): 49-54.

56 Sebastiany E, Rego ER, Vital MJS. Qualidade microbiológica de polpa de frutas congeladas. Rev. Inst. Adolfo Lutz. 2009; 68(2): 224-231.

57 Sebastiany E, Rego ER, Vital MJS. Avaliação do processo produtivo de polpas de frutas congeladas. Rev. Inst. Adolfo Lutz. 2010; 69(3): 318-326.

58 Faria M, Oliveira LBD, Costa FEC. Qualidade microbiológica de polpas de açaí congeladas. Alim. Nutr. 2012; 23(2): 243-249.

59 Souza BA, Lopes ES, Fortuna JL, Macena TNS. Análise microbiológica e higiênicosanitária de polpas de frutas comercializadas em supermercados do município de Teixeira de Freitas-BA. Revista Higiene Alimentar. 2011; 25(194/195): 1022-1024.

60 Souza GC, Carneiro JG, Gonçalves HRO. Qualidade microbiológica de polpas de frutas congeladas produzidas no município de Russas - CE. ACSA - Agrop. Cient. Semiárido. 2011; 7(3): 1-5.

61 Brito CS, Rossi DA. Bolores e leveduras, coliformes totais e fecais em sucos de laranja in natura e industrializados nao pasteurizados comercializados na cidade de Uberlandia-MG. Biosci. J. 2005; 21(1): 133-140.

62 Furtini LLR, Abreu LR. Utilização do APPCC na Indústria de Alimentos. Rev. Cienc Agrotec. 2006; 30(2): 358-363.

63 Peretti APR, Araujo WMC. Abrangência do requisito segurança em certificados de qualidade da cadeia produtiva de alimentos no Brasil. Gest. Prod. 2010; 17(1): 35-49. 
Tropical fruit pulp: main parameters to control

64 Profeta RA, Silva SF. APPCC - Análises de Perigos e Pontos Críticos de Controle na Empresa de Açúcar. In: XXV ENEGEP -Encontro Nacional de Engenharia de Produção, 29 october 2005; Porto Alegre.

65 Pardo JE, Snachez JE, Perez JI, Andres M, Alvarruiz A. Aplicaciòn del sistema de analisis de peligros y puntos de control critico (APPCC) em la linea de envasado de aceite de oliva virgen. Grasas Aceites. 2003; 54(1): 58-64.

66 Cruz AG, Cenci SA, Maia MCA. Pré-requisitos para implementação do sistema APPCC em uma linha de alface minimamente processada. Food Sci. Technol. 2006; 26(1): 104-109. 